\title{
A novel alkaline protease from wild edible mushroom Termitomyces albuminosus
}

\author{
Suyue Zheng ${ }^{1,2}$, Hexiang Wang ${ }^{2 \bowtie}$ and Guoqing Zhang ${ }^{3 凶}$ \\ ${ }^{1}$ Hebei Engineering University, Handan, China; ${ }^{2}$ State Key Laboratory for Agrobiotechnology and Department of Microbiology, China Agricul- \\ tural University, Beijing, China; ${ }^{3}$ Key Laboratory of Urban Agriculture (North) of Ministry of Agriculture, Beijing University of Agriculture, Beijing, \\ China
}

\begin{abstract}
A protease with a molecular mass of $30 \mathrm{kDa}$ and the $\mathrm{N}$ terminal sequence of GLQTNAPWGLARSS, was isolated from fresh fruiting bodies of the wild edible mushroom Termitomyces albuminosus. The purification protocol included ion exchange chromatography on DEAE-cellulose, Q-Sepharose, SP-Sepharose and FPLC-gel filtration on Superdex 75. The protein was unadsorbed on DEAE-cellulose and Q-Sepharose, but adsorbed on SP-Sepharose. The optimal $\mathrm{pH}$ and temperature of the purified enzyme were 10.6 and $60^{\circ} \mathrm{C}$, respectively. The enzyme was stable in the presence of $2 \%(\mathrm{v} / \mathrm{v})$ Tween 80 and $4 \mathrm{M}$ urea. More than $80 \%$ of the enzyme activity was retained in $2 \%(\mathrm{v} / \mathrm{v})$ Triton $X 100,54 \%$ in $10 \mathrm{mM}$ EDTA and $31 \%$ in $2 \%(w / v)$ SDS. The enzyme was strongly inhibited by phenylmethylsulfonyl fluoride (PMSF), but not inhibited by dithiothreitol (DTT), pepstatin or lima bean trypsin inhibitor suggesting that it was a serine protease but not a trypsin-like one. The protease was inhibited by $\mathrm{Hg}^{2+}$ $\mathrm{Cu}^{2+}$, and $\mathrm{Fe}^{3+}$ ions. The $K_{\mathrm{m}}$ and $V_{\text {max }}$ values of the purified enzyme for casein were $8.26 \mathrm{mg} \cdot \mathrm{ml}^{-1}$ and $0.668 \mathrm{mg} \cdot \mathrm{ml}^{-1}$ $\cdot$ min $^{-1}$, respectively.
\end{abstract}

Keywords: alkaline protease, mushroom, Termitomyces albuminosus, purification

Received: 02 April, 2011; revised: 26 May, 2011; accepted:

11 June, 2011; available on-line: 16 June, 2011

\section{INTRODUCTION}

Proteases are ubiquitous, being found in a wide diversity of sources such as plants, animals, and microorganisms. They are degradative enzymes which catalyze the hydrolysis of proteins. Proteases not only play an important role in the cellular metabolic processes (Tremacoldi et al., 2007), but also have many applications in detergents, leather processing, silver recovery, medical purposes, food processing, feeds, the chemical industry, as well as waste treatment (Ma et al., 2007). The serine proteases are characterized by the presence of a serine group in their active site. They are vital to the organisms and the most important group of commercial enzymes. Alkaline serine proteases are active and stable in the alkaline $\mathrm{pH}$ and represent the largest subgroup of serine proteases. The optimal $\mathrm{pH}$ of alkaline proteases is around $\mathrm{pH} 10$, and their isoelectric point is around $\mathrm{pH} 9$ ( $\mathrm{RaO}$ et al., 1998). The properties of alkaline serine proteases make them suitable for use in the detergent industry. Presently, some proteases from mushroom have been purified (Terashita et al., 1985; Yoshimoto et al., 1988; Kobayashi et al., 1989; Sattar et al., 1990; Shaginian et al., 1990; Bur- ton et al., 1994; Nonaka et al., 1995; 1997; Shin \& Choi, 1998; Healy et al., 1999; Kim \& Kim, 1999, 2001; Wang \& Ng, 2001; Cui et al., 2007; Zhang et al., 2010a, 2010b).

Termitomyces albuminosus, a well-known symbiotic wild mushroom occurred on the surface of termite nests, also called chicken julienne mushroom or termite mushroom, is a long-stemmed mushroom grown in Yunnan province (China). The termites cultivate this fungus in nests as their food. Enzymes as peroxidase (Johjima et al., 2003; Liers et al., 2010) and laccase (Bose et al., 2007) have been isolated from T. albuminosus. In this work, we describe the isolation and general properties of a novel alkaline serine protease from $T$. albuminous, and compared its characteristics to other mushroom serine protease.

\section{MATERIALS AND METHODS}

Materials. Fresh fruiting bodies of the mushroom T. albuminosus were purchased from Kunming City, Yunnan Province (China). Superdex 75 HR 10/30, QSepharose, SP-Sepharose and AKTA Purifier were from GE Healthcare. All other chemicals were obtained from Sigma Chemical Co., USA.

Isolation procedure. Fresh fruiting bodies of the mushroom were homogenized in $0.15 \mathrm{M} \mathrm{NaCl}$ at $4{ }^{\circ} \mathrm{C}$ overnight. The supernatant was centrifuged at $8000 \times \mathrm{g}$ for $15 \mathrm{~min}$ before $\left(\mathrm{NH}_{4}\right)_{2} \mathrm{SO}_{4}$ was added to $80 \%$ saturation. The precipitate was collected by centrifugation at $8000 \times \mathrm{g}$ for $15 \mathrm{~min}$ again. Then the precipitate was dissolved and dialyzed to remove $\left(\mathrm{NH}_{4}\right)_{2} \mathrm{SO}_{4}$ before applying to a column $(2.5 \mathrm{~cm} \times 20$ $\mathrm{cm}$ ) of DEAE-cellulose, which had previously been equilibrated and then eluted with $10 \mathrm{mM} \mathrm{NH} \mathrm{NHCO}_{3}$ buffer ( $\mathrm{pH}$ 9.4). After collecting the unadsorbed peak (D1) containing strong protease activity, two adsorbed peaks, D2 and D3, were eluted with 100 $\mathrm{mM}$ and $1 \mathrm{M} \mathrm{NaCl}$ in the starting buffer, respectively. Fraction D1 with protease activity was applied directly on a column $(1.5 \mathrm{~cm} \times 20 \mathrm{~cm})$ of Q-Sepharose in $10 \mathrm{mM} \mathrm{NH}_{4} \mathrm{HCO}_{3}$ buffer (pH 9.4). Unbound proteins (fraction Q1) were eluted with the starting buffer while bound proteins (fraction Q2) were desorbed with $1 \mathrm{M} \mathrm{NaCl}$ in the starting buffer. Following dialysis, the active fraction Q1 was subject onto

e-mails: hxwang@cau.edu.cn (H.X. Wang);

Zhanggq1001@gmail.com (G.Q. Zhang

Abbreviations: DTT, dithiothreitol; PMSF, phenylmethylsulfonyl fluoride 
a SP-Sepharose chromatography column $(1.5 \mathrm{~cm} \times 10$ $\mathrm{cm})$ in $\mathrm{pH} 7.5$ phosphate buffer. Unadsorbed proteins (fraction S1) were eluted with the same buffer while adsorbed proteins were eluted with a linear concentration gradient of $\mathrm{NaCl}(0-0.3 \mathrm{M})$ in the phosphate buffer to obtain adsorbed fractions S2, S3, respectively. Protease activity was detected in S2. The active fraction (S2) was subsequently chromatographed on a Superdex 75 HR 10/30 column (GE Healthcare) in $0.15 \mathrm{M} \mathrm{NH}_{4} \mathrm{HCO}_{3}$ buffer (pH 8.5) using an AKTA Purifier. Two peaks (SU1 and SU2) were obtained. All the above purification procedures were conducted at $4{ }^{\circ} \mathrm{C}$. The second peak (SU2) with protease activity was then analyzed by sodium dodecyl sulfate/polyacrylamide gel electrophoresis (SDS/PAGE) (Laemmli \& Favre, 1973). The N-terminal sequence was determined by using a HewlettPackard HP G1000A Edman degradation unit and an HP1000 HPLC system (Lam et al., 1998.

Assay for protease activity. The protease activity was determined at $37^{\circ} \mathrm{C}$ in phosphate buffer $(\mathrm{pH} 7.0$, $50 \mathrm{mM}$ ) by a method of Cui et al. (2007). One unit of protease activity is defined as an absorbance increase of 0.001 at $280 \mathrm{~nm}$ in the sample per $\mathrm{ml}$ reaction mixture per minute under the experimental conditions. Protein concentrations were determined according to the method of Bradford using bovine serum albumin as a standard (Bradford, 1976).

Effect of $\mathrm{pH}$ and temperature on enzyme activity. In order to determine the effect of $\mathrm{pH}$ values on the purified enzyme, the protease activity was measured at different $\mathrm{pH}$ values. The $\mathrm{pH}$ values of the reaction mixture were adjusted using one of the following buffers: citric acid/sodium citrate ( $\mathrm{pH} 4.0_{-}$ 7.0, $50 \mathrm{mM}$ ), barbital sodium/HCl (pH 7.0-9.6, 50 $\mathrm{mM}), \mathrm{NaHCO}_{3} / \mathrm{NaOH}(\mathrm{pH} 9.6-11.0,50 \mathrm{mM}), \mathrm{KCl} /$ $\mathrm{NaOH}(\mathrm{pH} 12.0-13.0,50 \mathrm{mM})$. The purified protease $(10 \mu \mathrm{l})$ was incubated at $37^{\circ} \mathrm{C}$ for $15 \mathrm{~min}$ with $90 \mu \mathrm{l} 1 \%$ casein solution and $100 \mu \mathrm{l}$ assay buffer as described above. In the temperature effect assay, the activity of the protease was determined by incubating the reaction mixture at different temperature ranging from $20^{\circ} \mathrm{C}$ to $80^{\circ} \mathrm{C}$ for $15 \mathrm{~min}$ with phosphate buf-

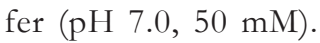

Effect of metal ions on protease activity. Purified protease solutions were pre-incubated at $4^{\circ} \mathrm{C}$ for $1 \mathrm{~h}$ with different metal ion solutions (phosphate buffer, $\mathrm{pH}$ 7.0, $50 \mathrm{mM}$ ) including $\mathrm{Mg}^{2+}, \mathrm{Ca}^{2+}, \mathrm{Mn}^{2+}, \mathrm{Cu}^{2+}$, $\mathrm{Co}^{2+}, \mathrm{Hg}^{2+}, \mathrm{Pb}^{2+}, \mathrm{Zn}^{2+}$ and $\mathrm{Fe}^{3+}$, at a final concentration of $1 \mathrm{mM}$ or $5 \mathrm{mM}$. The residual activity was assayed as described above.

Enzyme kinetics. Casein at different concentrations $(2 \%, 1 \%, 0.5 \%, 0.2 \%, 0.1 \%, 0.08 \%, 0.06 \%$, $0.04 \%, 0.02 \%$ ) was used as a substrate. The $K_{\mathrm{m}}$ and $V_{\max }$ of the enzyme were calculated based on a Lineweaver-Burk plot constructed by plotting the reciprocal of substrate concentration on the $\mathrm{X}$-axis, and the reciprocal of the enzyme reaction velocity on the $\mathrm{Y}$ axis. The enzyme activity was measured at $37^{\circ} \mathrm{C}$ with $\mathrm{NaHCO}_{3} / \mathrm{NaOH}$ buffer (pH 10.6, $50 \mathrm{mM}$ ) for 15 min. The experiment was repeated twice and results were reproducible.

Effect of inhibitors and other chemical reagents on protease activity. The effect of inhibitors on the enzyme activity was determined by its pre-incubation at room temperature (about $30^{\circ} \mathrm{C}$ ) for $30 \mathrm{~min}$, in the presence of $5 \mathrm{mM}$ phenylmethanesulfonyl fluoride (PMSF), $1 \mathrm{mM}$ or $10 \mathrm{mM}$ EDTA, $0.2 \mathrm{mM}$ pep-

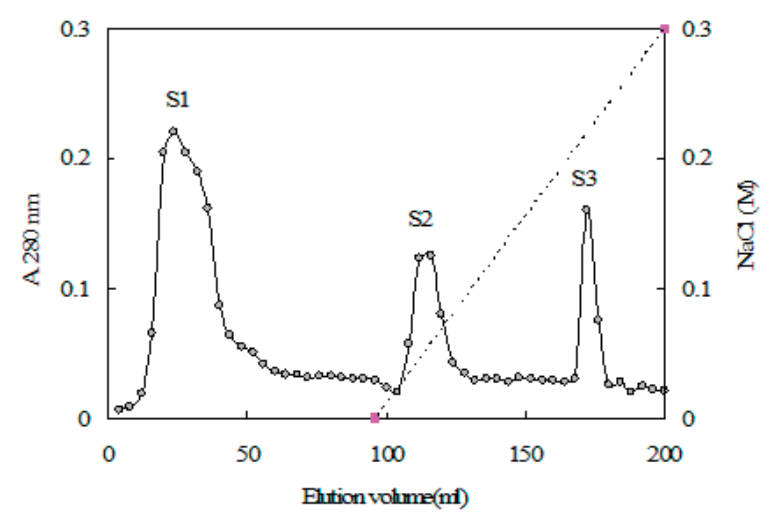

Figure 1. Anion exchange chromography of fraction Q1 on a SPSepharose.

Starting buffer: $10 \mathrm{mM}$ phosphate buffer ( $\mathrm{pH} 7.5)$.

statin, $0.25 \mathrm{mM}$ lima bean trypsin inhibitor, $1 \mathrm{mM}$ dithiothreitol (DTT), $1 \%$ or 2\% 2-mercaptoethanol. All the solutions were in phosphate buffer $(\mathrm{pH} 7.0$, $50 \mathrm{mM}$ ). The enzyme activity was also measured in the presence of $1 \%$ or $2 \%$ Triton X 100, SDS and Tween 80, $4 \mathrm{M}$ urea, $25 \mathrm{mM} \mathrm{HCl}$ and $25 \mathrm{mM} \mathrm{NaOH}$. After pre-incubation, the residual enzyme activity was measured. The enzyme activity of a control sample (without any inhibitors and other chemicals) was taken as 100 .

\section{RESULTS}

\section{Purification of the protease}

Protease activity resided in fraction D1 of the crude extract unadsorbed on DEAE-cellulose. The adsorbed fractions D2 and D3 had weak protease activity (Table 1). Fraction D1 was resolved into an unadsorbed fraction Q1 and adsorbed fractions Q2 upon ion exchange chromatography on Q-Sepharose. The protease activity was detected mainly in the unadsorbed fraction Q1 (Table 1). Fraction Q1 was collected for further purification on a SP-Sepharose column. The activity was eluted with a linear gradient of $0-0.3 \mathrm{M} \mathrm{NaCl}$ in $10 \mathrm{mM}$ phosphate buffer ( $\mathrm{pH} 7.5$ ). Three peaks (S1, S2, and S3) were obtained, but only

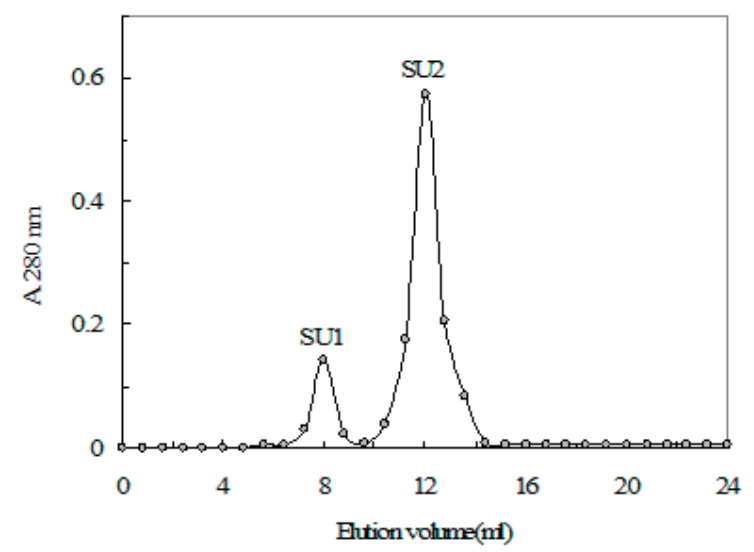

Figure 2. Gel filtration of fraction S2 on Superdex 75 HR 10/30 column 
Table 1. Yields and protease activities of chromatographic fractions toward casein

Purification was from $60 \mathrm{~g}$ of fresh T. albuminosus fruiting bodies

\begin{tabular}{|c|c|c|c|c|c|}
\hline Fraction & $\begin{array}{l}\text { Total } \\
\text { protein } \\
\text { (mg) }\end{array}$ & $\begin{array}{l}\text { Specific } \\
\text { activity } \\
(\mathrm{U} / \mathrm{mg})\end{array}$ & $\begin{array}{l}\text { Total } \\
\text { activity } \\
\left(\mathrm{U} / 10^{5}\right)\end{array}$ & $\begin{array}{l}\text { Activity } \\
\text { recovery } \\
(\%)\end{array}$ & Fold purification \\
\hline Ammonium sulfate precipitate & 443.2 & 6293.0 & 27.9 & 100.0 & 1.0 \\
\hline D1 & 40.3 & 43634.5 & 17.6 & 63.1 & 6.9 \\
\hline D2 & 18.7 & 9126.3 & 1.7 & 6.1 & 1.5 \\
\hline D3 & 93.9 & 3420.8 & 3.2 & 11.5 & 0.5 \\
\hline Q1 & 27.3 & 53688.5 & 14.6 & 52.5 & 8.5 \\
\hline Q2 & 10.0 & 3716.0 & 0.4 & 1.3 & 0.6 \\
\hline S1 & 7.5 & 0 & 0 & 0 & 0 \\
\hline S2 & 6.4 & 184919.8 & 11.8 & 42.2 & 29.4 \\
\hline S3 & 3.8 & 0 & 0 & 0 & 0 \\
\hline SU1 & 0.72 & 0 & 0 & 0 & 0 \\
\hline SU2 & 3.45 & 198260.9 & 6.84 & 24.52 & 31.5 \\
\hline
\end{tabular}

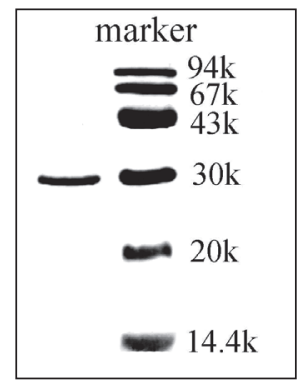

Figure 3. SDS/PAGE of $T$. albuminosus protease Left lane: T. albuminosus serine protease. Right lane: Relative molecular mass standards.

S2 possessed high protease activity (Fig. 1, Table 1). Fraction S2 was fractionated into a small inactive fraction SU1 and a large active fraction SU2 upon FPLCgel filtration on Superdex 75 (Fig. 2, Table 1). The protease appeared as a single band with a molecular mass of $30 \mathrm{kDa}$ in SDS/PAGE (Fig. 3). The yields and specific protease activities at the various stages of purification are shown in Table 1. The N-terminal amino-acid sequence was GLQTNAPWGLARLSS,

Table 2. Effects of metal ions on T. albuminosus protease activity

\begin{tabular}{lrr}
\hline \multirow{2}{*}{ Metal ions } & \multicolumn{2}{c}{ Relative activity remaining (\%) } \\
\cline { 2 - 3 } & $1 \mathrm{mM}$ & $5 \mathrm{mM}$ \\
\hline Control & 100 & 100 \\
$\mathrm{Ca}^{2+}$ & 81.9 & 76.3 \\
$\mathrm{Mg}^{2+}$ & 93.5 & 72.7 \\
$\mathrm{Mn}^{2+}$ & 86.2 & 78.8 \\
$\mathrm{Cu}^{2+}$ & 69.9 & 16.7 \\
$\mathrm{~Pb}^{2+}$ & 104.7 & 56 \\
$\mathrm{Co}^{2+}$ & 85.3 & 56.8 \\
$\mathrm{Zn}^{2+}$ & 82.2 & 50.1 \\
$\mathrm{Hg}^{2+}$ & 5 & 0 \\
$\mathrm{Fe}^{3+}$ & 65.3 & 17.4 \\
\hline
\end{tabular}

which manifested considerable similarity with previously isolated fungal serine proteases, especially those from Agaricus bisporus, Grifola frondosa and Hypsizigus marmoreus (Table 4).

\section{Biological activities of the protease}

The effect of temperature and $\mathrm{pH}$ on the activity of the protease is illustrated in Figs. 4 and 5. The optimum $\mathrm{pH}$ was around 10.6, and the optimum temperature was around $60^{\circ} \mathrm{C}$. Its $K_{\mathrm{m}}$ was $8.26 \mathrm{mg} / \mathrm{ml}$, and its $V_{\max }$ was $0.668 \mathrm{mg} \cdot \mathrm{ml}^{-1} \cdot \mathrm{min}^{1-}$. The effect of metal ions on the activity of the protease is shown in Table 2. The protease activity was inhibited strongly by $\mathrm{Hg}^{2+}, \mathrm{Cu}^{2+}$, and $\mathrm{Fe}^{3+}$. Among the protease inhibitors tested, only PMSF almost completely inhibited the protease activity. The activity of the protease is unaffected by pepstatin, lima bean trypsin inhibitor, DTT and 2-mercaptoethanol. The enzyme activity was enhanced by $25 \mathrm{mM} \mathrm{NaOH}$, and inhibited completely by $25 \mathrm{mM} \mathrm{HCl}$. Protease activity was not affected by Tween $80(2 \%, \mathrm{v} / \mathrm{v})$ or $4 \mathrm{M}$ urea under the assay

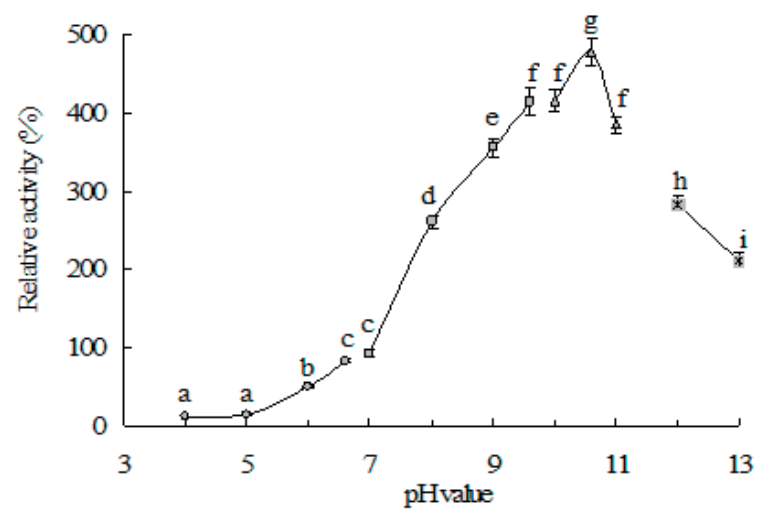

Figure 4. Effect of $\mathrm{pH}$ on activity of T. albuminosus protease Citric acid/sodium citrate buffer ( $\mathrm{pH}$ 4.00-7.0), barbital sodium/ $\mathrm{HCl}$ buffer (pH 7.0-9.6), $\mathrm{NaHCO}_{3}-\mathrm{NaOH}$ buffer $(\mathrm{pH}$ 9.6-11.0), KCl/NaOH $(\mathrm{pH} 12.0-13.0)$. Results represent mean \pm S.D. $(n=3)$. Different letters $(a, b, c \ldots)$ next to the data points indicate statistically significant difference $(p<0.05)$ when the data are analyzed by analysis of variance followed by Duncan's multiple range test. The activity at $\mathrm{pH} 7.0$ was taken as $100 \%$. 
Table 3. Influence of inhibitors and other chemicals on T. albuminosus protease activity

\begin{tabular}{lcc}
\hline Chemical & Concentration & $\begin{array}{c}\text { Residual activity } \\
\text { (\%) }\end{array}$ \\
\hline None & $0.2 \mathrm{mM}$ & 100 \\
\hline Pepstatin A & $1 \mathrm{mM}$ & 100 \\
\hline PMSF & $0.25 \mathrm{mM}$ & 100 \\
\hline Lima bean trypsin inhibitor & $1 \mathrm{mM}$ & 88 \\
\hline EDTA & $5 \mathrm{mM}$ & 62 \\
& $10 \mathrm{mM}$ & 54 \\
\hline DTT & $1 \mathrm{mM}$ & 96 \\
\hline $2-$ Mercaptoethanol & $1 \%$ & 100 \\
& $2 \%$ & 100 \\
\hline Triton X 100 & $1 \%$ & 84 \\
\hline SDS & $2 \%$ & 81 \\
\hline Tween 80 & $1 \%$ & 37 \\
\hline Urea & $2 \%$ & 31 \\
\hline HCl & $1 \%$ & 100 \\
\hline NaOH & $2 \%$ & 100 \\
\hline & $4 \mathrm{M}$ & 140 \\
\hline & $25 \mathrm{mM}$ & 0 \\
\hline & $25 \mathrm{mM}$ & 301 \\
\hline & & \\
\hline
\end{tabular}

condition. More than $80 \%$ of the activity was retained in $2 \%(\mathrm{v} / \mathrm{v})$ Triton X 100, 54\% in $10 \mathrm{mM} \mathrm{EDTA}$ and $31 \%$ in $2 \%(\mathrm{w} / \mathrm{v})$ SDS (Table 3$)$.

\section{DISCUSSION}

In this report, a protease with a molecular mass of $30 \mathrm{kDa}$ was isolated from fresh fruiting bodies of the mushroom T. albuminosus. Serine proteases are generally active at neutral and alkaline $\mathrm{pH}$, with an optimum between $\mathrm{pH} 7$ and 11, and molecular masses between 18 and $35 \mathrm{kDa}$ (Rao et al., 1998). The apparent molecular mass of $30 \mathrm{kDa}$ for the protease is similar to those of mushroom serine proteases from $A$. bisporus $(27 \mathrm{kDa})$ (Burton et al., 1993), P. citrinopileatus (28 kDa) (Cui et al., 2007), H. marmoreus (28 kDa) (Zhang et al., 2010b) and Helvella lacunose (33.5 kDa) (Zhang et al., 2010a). Its Nterminal sequence is considerably homologous to the previously isolated mushroom serine proteases from A. bisporus, G. frondosa, $H$. marmoreus, and P. citrinopileatus, but different from that of $H$. lacunosa (Table 4).

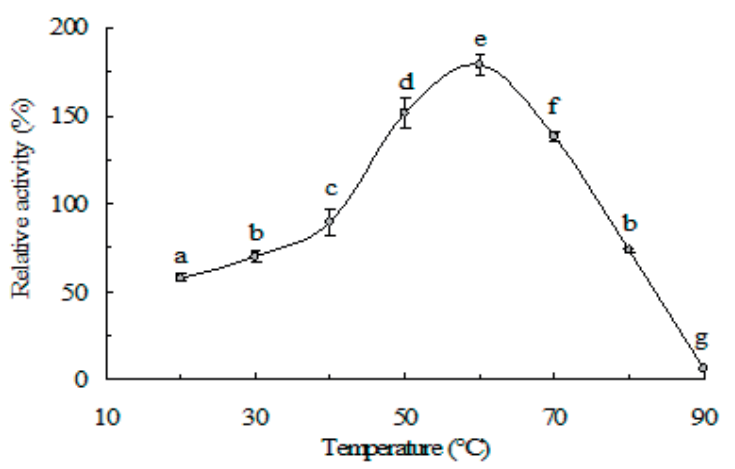

Figure 5. Effect of temperature on activity of $T$. albuminosus protease

Results represent mean \pm S.D. $(n=3)$. Different letters $(a, b, c \ldots)$ next to the data points indicate statistically significant difference $(p<0.05)$ when the data are analyzed by analysis of variance followed by Duncan's multiple range test. The activity at $\mathrm{pH} 7.0$ was taken as $100 \%$.

The protease showed a broad $\mathrm{pH}$ profile $(\mathrm{pH}$ 7.0-13.0) for casein hydrolysis. The highest activity appeared at $\mathrm{pH}$ 10.6. It is suggested that $T$. albuminosus protease might be classified into the family of alkaline proteases, which are represented mostly by serine proteases. Another prominent property of the purified protease is its relative thermostability. The optimal enzymatic activity of T. albuminosus protease is obtained at $60^{\circ} \mathrm{C}$, and $73 \%$ residual activity was measured at $80^{\circ} \mathrm{C}$. The optimum temperature is higher than for other fungal proteases from A. bisporus $\left(35^{\circ} \mathrm{C}\right)$ (Burton et al., 1997a; 1997b), P. citrinopileatus $\left(50^{\circ} \mathrm{C}\right.$ ) (Cui et al., 2007) and H. marmoreus $\left(50^{\circ} \mathrm{C}\right)$ (Zhang et al., 2010b).

The activity of purified protease was inhibited by PMSF, but not by other inhibitors, e.g., pepstatin, lima bean trypsin inhibitor, DT'T or 2-mercaptoethanol. The strong inhibition by $1 \mathrm{mM}$ PMSF may be an indication that the enzyme belongs to the serine protease family. The enzyme was resistant to thiol reducing agents such as DTT $(1 \mathrm{mM})$ and 2 -mercaptoethanol $(2 \%)$, suggesting that disulfide bonding was not involved in preserving proteolytic activity. EDTA had an inhibitory effect on the enzyme activity at $10 \mathrm{mM}$ concentration, indicating that the enzyme is sensitive to EDTA. The protease activity was not affected by Tween $80(2 \%, \mathrm{v} / \mathrm{v})$ or $4 \mathrm{M}$ urea under the assay condition. More than $80 \%$ of the activity was retained in $2 \%(\mathrm{v} / \mathrm{v})$ Triton X 100 . The enzyme was insensitive to Triton X 100, Tween 80 and the denaturing agent urea, rather stable in $50-70^{\circ} \mathrm{C}$, and had high activity at high $\mathrm{pH}$. This suggested that the enzyme could have potential applications in detergent uses, such as brewing and leather industries (Dayanandan et al., 2003; Ganesh et al., 2008).

In summary, we have reported the purification and characterization of a novel protease from the wild mushroom T. albuminosus. The purified enzyme manifested a molecular mass of $30 \mathrm{kDa}, \mathrm{N}$ -

terminal amino-acid semushroom serine proteases

\begin{tabular}{|c|c|c|}
\hline Proteinase & $\mathrm{N}$-terminal sequence & Reference \\
\hline Serine protease [Termitomyces albuminosus] & GLQTN APWGL ARLSS & This study \\
\hline Serine protease [Agaricus bisporus] & TGQTN $\underline{\text { APWGL }} \underline{\text { ARLXX }}$ & (Burton et al., 1993) \\
\hline Serine protease [Grifola frondosa] & AQTN $\underline{\text { APWGL }} \underline{\text { ARISS }}$ & BLAST search \\
\hline Serine protease [Hypsizigus marmoreus] & VTQTN $\underline{\text { APWGL ARLSQ }}$ & (Zhang et al., 2010b) \\
\hline Serine protease [Helvella lacunosa] & ANVVQ WPVPC & (Zhang et al., 2010a) \\
\hline Serine protease [Pleurotus citrinopileatus] & VCQQCN $\underline{\text { APWGL }}$ & (Cui et al., 2007) \\
\hline
\end{tabular}


quence of GLQTNAPWGLARLSS, a pH optimum of 10.6 and a temperature optimum of $60^{\circ} \mathrm{C}$. The protease was inhibited by $\mathrm{Hg}^{2+}, \mathrm{Cu}^{2+}$, and $\mathrm{Fe}^{3+}$ ions. The $K_{m}$ and $V_{\max }$ values of the purified enzyme for casein were 8.26 $\mathrm{mg} \cdot \mathrm{ml}^{-1}$ and $0.668 \mathrm{mg} \cdot \mathrm{ml}^{-1} \cdot \mathrm{min}^{-1}$, respectively. Its alkaline $\mathrm{pH}$ optimum and sensitivity to PMSF suggested that the purified enzyme was an alkaline serine protease.

\section{Acknowledgements}

This work was financially supported by National Grants of China (2010CB732202).

\section{REFERENCES}

Bose S, Mazumder S, Mukherjee M (2007) Laccase production by the white-rot fungus Termitomyces clypeatus. J Basic Microbiol 47: 127-131.

Bradford MM (1976) A rapid and sensitive method for the quantitation of microgram quantities of protein utilizing the principle of proteindye binding. Anal Biochem 72: 248-254.

Burton KS, Wood DA, Thurston CF, Barker PJ (1993) Purification and characterization of a serine proteinase from senescent sporophores of the commercial mushroom Agaricus bisporus. I Gen Microbiol 139: 1379-1386.

Burton KS, Hammond JBW, Minamide T (1994) Protease activity in Agaricus bisporus during periodic fruiting (flushing) and sporophore development. Curr Microbiol 28: 275-278.

Burton KS, Partis MD, Wood DA, Thurston CF (1997a) Accumulation of serine proteinase in senescent sporophores of the cultivated mushroom, Agaricus bisporus. Mycol Res 101: 146-152.

Burton KS, Smith JF, Wood DA, Thurston CF (1997b) Mycelial proteinases of the cultivated mushroom Agaricus bisporus. Mycol Res 101: 1341-1347.

Cui L, Liu QH, Wang HX, Ng TB (2007) An alkaline protease from fresh fruiting bodies of the edible mushroom Pleurotus citrinopileatus. Appl Microbiol Biotechnol 75: 81-85.

Dayanandan A, Kanagaraj J, Sounderraj L, Govindaraju R, Rajkumar GS (2003) Application of an alkaline protease in leather processing: an ecofriendly approach. J Clean Prod 1: 533-536.

Ganesh KA, Swarnalatha S, Sairam B, Sekaran G (2008) Production of alkaline protease by Pseudomonas aeruginosa using proteinaceous solid waste generated from leather manufacturing industries. Bioresour Technol 9: 1939-1944.

Healy V, O'Connell J, McCarthy TV, Doonan S (1999) The lysine-specific proteinase from Armillaria mellea is a member of a novel class of metalloendopeptidases located in Basidiomycetes. Biochem Biophys Res Commun 2: 60-63.

Johjima T, Ohkuma M, Kudo T (2003) Isolation and cDNA cloning of novel hydrogen peroxide-dependent phenol oxidase from the basidiomycete Termitomyces albuminosus. Appl Microbiol Biotechnol 1: 220-225.

Kim JH, Kim YS (1999) A fibrinolytic metalloprotease from the fruiting bodies of an edible mushroom, Armillariella mellea. Biosci Biotechnol Biochem 3: 2130-2136.
Kim JH, Kim YS (2001) Characterization of a metalloenzyme from a wild mushroom, Tricholoma saponaceum. Biosci Biotechnol Bioch 65: 356-362.

Kobayashi H, Sekibata S, Shibuya H, Yoshida S, Kusakabe I, Murakami K (1989) Cloning and sequence analysis of cDNA for Irpex lacteus aspartic proteinase. Agric Biol Chem 53: 1927-1933.

Laemmli UK, Favre M (1973) Maturation of the head of bacteriophage T4. I. DNA packaging events. J Mol Biol 80: 575-599.

Lam SS, Wang H, Ng TB (1998) Purification and characterization of novel ribosome inactivating proteins, alpha- and beta-pisavins, from seeds of the garden pea Pisum sativum. Biochem Biophys Res Coun 253: 135-142.

Liers C, Bobeth C, Pecyna M, Ullrich R, Hofrichter M (2010) DyP-like peroxidases of the jelly fungus Auricularia auricula-judae oxidize nonphenolic lignin model compounds and high-redox potential dyes. Appl Microbiol Biotechnol 85: 1869-1879.

Ma C, Ni X, Chi Z, Ma L, Gao L (2007) Purification and characterization of an alkaline protease from the marine yeast Aureobasidium pullulans for bioactive peptide production from different sources. Mar Biotechnol (NY) 9: 343-351.

Nonaka T, Ishikawa H, Tsumuraya Y, Hashimoto Y, Dohmae N (1995) Characterization of a thermostable lysine-specific metalloendopeptidase from the fruiting bodies of a basidiomycete. Grifola frondosa. J Biochem 118: 1014-1020.

Nonaka T, Dohmae N, Hashimoto Y, Takio K (1997) Amino acid sequences of metalloendopeptidases specific for acyl-lysine bonds from Grifola frondosa and Pleurotus ostreatus fruiting bodies. J Biochem 272: 30032-30039.

Rao MB, Tanksale AM, Ghatge MS, Deshpande VV (1998) Molecular and biotechnological aspects of microbial proteases. Microbiol Mol Biol Rev 62: 597-635.

Sattar AK, Yamamoto N, Yoshimoto T, Tsuru D (1990) Purification and characterization of an extracellular prolyl endopeptidase from Agaricus bisporus. Biochem 107: 256-261.

Shaginian KA, Alekhina IA, Denisova NP (1990) Serine proteinase from the higher basidiomycetes of Coprinus genus. Biokbimiia 55: 1387-1395.

Shin HH, Choi HS (1998) Purification and partial characterization of a metalloprotease in Flammulina velutipes. J Microbiol. 36: 20-25.

Terashita T, Oda K, Kona M, Murao S (1985) Purification and some properties of metal proteinases from Lentinus edodes. Agr Biol Chem 410: 2293-2300.

Tremacoldi CR, Monti R, Selistre HS, Carmona EC (2007) Purification and properties of an alkaline protease of Aspergillus clavatus. World J Microol Biotechnol 23: 295-299.

Wang H, Ng TB (2001) Pleureryn, a novel protease from fresh fruiting bodies of the edible mushroom Pleurotus eryngii. Biochem Biophys Res Commun 289: 750-755.

Yoshimoto T, Sattar AK, Hirose W, Tsuru D (1988) Studies on prolyl endopeptidase from shakashimeji (Lyophyllum cinerascens): purification and enzymatic properties. J Biochem 104: 622-627.

Zhang G, Wang H, Zhang X, Ng T (2010a) Helvellisin, a novel alkaline protease from the wild ascomycete mushroom Helvella lacunos $J$ Biosci Bioeng 109: 20-24.

Zhang XQ, Liu QH, Zhang GQ, Wang HX, Ng TB (2010b) Purification and molecular cloning of a serine protease from the mushroom Hypsizigus marmore. Process Biochem 45: 724-30. 